\title{
Feeding ecology of Assamese macaques (Macaca assamensis) troops in Kaligandaki and Budhigandaki River basins of central Nepal
}

\author{
SUVAS CHANDRA GHIMIRE ${ }^{1,2}$, LAXMAN KHANAL $^{1, \bullet}$, MUKESH KUMAR CHALISE $^{1}$ \\ ${ }^{1}$ Central Department of Zoology, Institute of Science and Technology, Tribhuvan University. Kathmandu 44618, Nepal \\ ${ }^{2}$ Department of Zoology, Amrit Science Campus, Tribhuvan University. Kathmandu 44600, Nepal. •email: 1khanal@cdztu.edu.np
}

Manuscript received: 2 March 2021. Revision accepted: 10 June 2021.

\begin{abstract}
Ghimire SC, Khanal L, Chalise MK. 2021. Feeding ecology of Assamese macaques (Macaca assamensis) troops in Kaligandaki and Budhigandaki River basins of central Nepal. Biodiversitas 22: 2625-2634. Seasonal fluctuations in the availability of key food resources impact the foraging behavior of animals. This study aimed to examine the seasonal variations in feeding time of Assamese macaques (Macaca assamensis) in the sub-tropical deciduous riverine forest environment of central Nepal. Two troops of Nepal population of Assamese macaques, a troop from Kaligandaki River Basin (KRBT) and the next from Budhigandaki River Basin (BRBT) were studied by focal animal sampling method. Data from systematic behavioral observations were analyzed with reference to that of the vegetation surveys. Assamese macaques invested more than two-fifths $(>40 \%)$ of the diurnal time on feeding. The KRBT consumed 71 plant species and the BRBT relied on 69 food plants. Leaves, mature and young, constituted the most dominant food item followed by the fruits and seeds. The two study troops inhabiting highly similar habitats of food plants (Sorensen's Similarity Index = 0.93) didn't have a significant difference in the selection of food-plant parts. However, the remarkable temporal difference in feeding plant parts was observed in concordance with their seasonal availability. Young leaves, when available during the spring and premonsoon were the major food items. Contrastingly, mature leaves were the food items during the winter on which animals were forced to rely when young leaves were scarce. We conclude that food choice and time investment on the feeding of different plant parts differ depending on the availability of food in the area. Macaques living in comparable habitats with similar food plants have analogous food choices and time investments.
\end{abstract}

Keywords: Feeding behavior, food choice, Macaca assamensis, seasonal variation, time investment

\section{INTRODUCTION}

Food availability and other environmental factors, which vary in time and space, influence the activity budgets of primates (Majolo et al. 2013; McFarland et al. 2014). Seasonal variation in food availability results in many primates altering their ranging patterns, activity budget, and/ or showing dietary flexibility in response to the availability of preferred and fallbacks (Hemingway and Bynum 2005; Knott 2005; Grueter 2017). Primates display a wide array of dietary and behavioral adaptations to maintain adequate food during periods of food scarcity (Serckx et al. 2015; Clink et al. 2017). Among them, frugivores tend to have longer daily travel distances than folivores because fruits are usually more patchily distributed than leaves (Chapman et al. 1995). In response to seasonal food shortages, primates often display behavioral plasticity by incorporation of alternate plant parts and human foods including crops and provisioned items. Additionally, they exhibit differences in activity, ranging and grouping patterns (Cabana et al. 2017; Frechette et al. 2017; McLennan et al. 2017). They maximize net energy intake like energy maximizers when high-quality food is most available and adopt an energyconserving strategy during periods of lower food availability ( $\mathrm{Ni}$ et al. 2015).

Assamese macaque (Macaca assamensis) is one among six extant species under the Sinica-group of macaques
(Khanal et al. 2021). It is categorized as Near Threatened by the IUCN Red List of Threatened Species (Boonratana et al. 2020) and listed on Appendix II of the Convention on International Trade in Endangered Species (CITES). Its Nepalese population, one of the least studied primates, is nationally listed as endangered due to its restricted distribution, population threats, and small numbers in fragmented patches of the remaining habitat (Chalise 2013; Khanal et al. 2019). Additionally, a recent phylogenetic analysis has suggested a distinct species status of the Nepal population of the Assamese macaques emphasizing the need for their conservation intervention (Khanal et al. 2021). It has been reported from the mid-hills of Nepal as a sub-tropical habitat specialist and more than half of the population is residing outside the protected area system (Khanal et al. 2019). The sporadically distributed populations in fragmented habitats, isolated by physiographic barriers like rivers and mountains, display variations in both morphology and behavior at different latitudes and elevations (Chalise 2008, 2013; Khanal et al. $2018,2019)$. The species has been described as a cropraider in many parts of Nepal (Chalise 2010; Paudel 2017; Adhikari et al. 2018; Ghimire and Chalise 2018, 2019). However, the details on its socio-ecology and conservation status are yet to be documented.

The Assamese macaque population in Nepal is distributed along with a narrow elevational range of midhills (Chalise 2013; Khanal et al. 2019) and it is a habitat 
specialist requiring broad-leaved riverine forest (Khanal et al. 2019). They live primarily in subtropical broadleaved forests. They spend a great deal of time in the high canopy and are also seen on the ground (Chalise 2003). More than half of the population currently resides outside protected areas of Nepal (Khanal et al. 2019) and incidents of human-macaque conflict, especially driven by crop-raiding, are high. Therefore, this species' socio-ecology and general ecology need to be examined in detail as such information could be of great importance to the conservation of this macaque species.

Understanding the temporal availability of food to a particular species is crucial when examining the drivers of their feeding strategies (Bessa et al. 2015). Assamese macaques are habitat specialists with a narrow home-range for which the distribution is mainly concentrated in the riverine broad-leaved forests. Such areas experience a remarkable seasonal variation in resource availability. However, the response of the macaques to such variations in the accessibility of food resources is understudied in Nepal. Therefore, this study assessed how seasonal changes in food availability influence the feeding behavior of Assamese macaques. Over a twelve-month period, data from systematic behavioral observations were analyzed with reference to that of the vegetation surveys. We aimed to explore i) major food plants and their parts for the macaque, and, ii) temporal variations in food preference by the Assamese macaques in two different river basins. By the analysis of feeding time investment on different food items, this study improves our understanding of the feeding ecology of Assamese macaques living in the riverine forests of Kaligandaki and Budhigandaki rivers in central Nepal.

\section{MATERIALS AND METHODS}

\section{Study area}

This study was conducted for 12 months from February 2015 to January 2016 at Kaligandaki River Basin and Budhigandaki River Basin of central Nepal (Figure 1). Kaligandaki River Basin (KRB, Ramdi to Ranimahal covering about $80 \mathrm{~km}^{2}$ ) is situated between $27^{\circ} 54^{\prime} 9.34^{\prime \prime}$ to $27^{\circ} 92^{\prime} 67^{\prime \prime} \mathrm{N}$ and $83^{\circ} 38^{\prime} 3.00^{\prime \prime}$ to $83^{\circ} 52^{\prime} 78^{\prime \prime} \mathrm{E}$ including areas of Palpa and Syangja districts (Figure 1). The altitude ranges from $420 \mathrm{~m}$ to $656 \mathrm{~m}$ above sea level (asl). The mean annual maximum and minimum temperatures of the area are $26.91^{\circ} \mathrm{C}$ and $15.18^{\circ} \mathrm{C}$, respectively. This area is rich in biodiversity, which may be due to the presence of alluvial soil along the basin of the Kaligandaki river and high productivity of tropical deciduous riverine forest (Chalise 2013). Mixed types of forest especially tropical deciduous riverine forest, sub-tropical grassland and subtropical evergreen forests found in the study area.

Budhigandaki River Basin (BRB, Benighat to Arughat, covering about $192 \mathrm{~km}^{2}$ ) is an area of Dhading and Gorkha districts. The study area lies about $2 \mathrm{~km}$ north of the confluence of Budhigandaki River with Trishuli River. The study area is situated between $27^{\circ} 48^{\prime} 54.48^{\prime \prime}$ to $28^{\circ} 04^{\prime} 68^{\prime \prime} \mathrm{N}$ and $84^{\circ} 46^{\prime} 33.63^{\prime \prime}$ to $84^{\circ} 81^{\prime} 25^{\prime \prime} \mathrm{E}$. The altitude ranges from $342 \mathrm{~m}$ to $582 \mathrm{~m}$ asl. The mean annual maximum and minimum temperatures of the area are $28.15^{\circ} \mathrm{C}$ and $16.15^{\circ} \mathrm{C}$, respectively. The area has mixed types of forest especially tropical deciduous riverine forest, sub-tropical grassland, and sub-tropical evergreen forests. Aerial distance between the Kaligandaki riverside (Ramdi) to Budhigandaki riverside (Benighat) is $112.99 \mathrm{~km}$. Study areas have four distinct seasons viz. spring (March-May), summer (June-August), autumn (September-November) and winter (December-February).

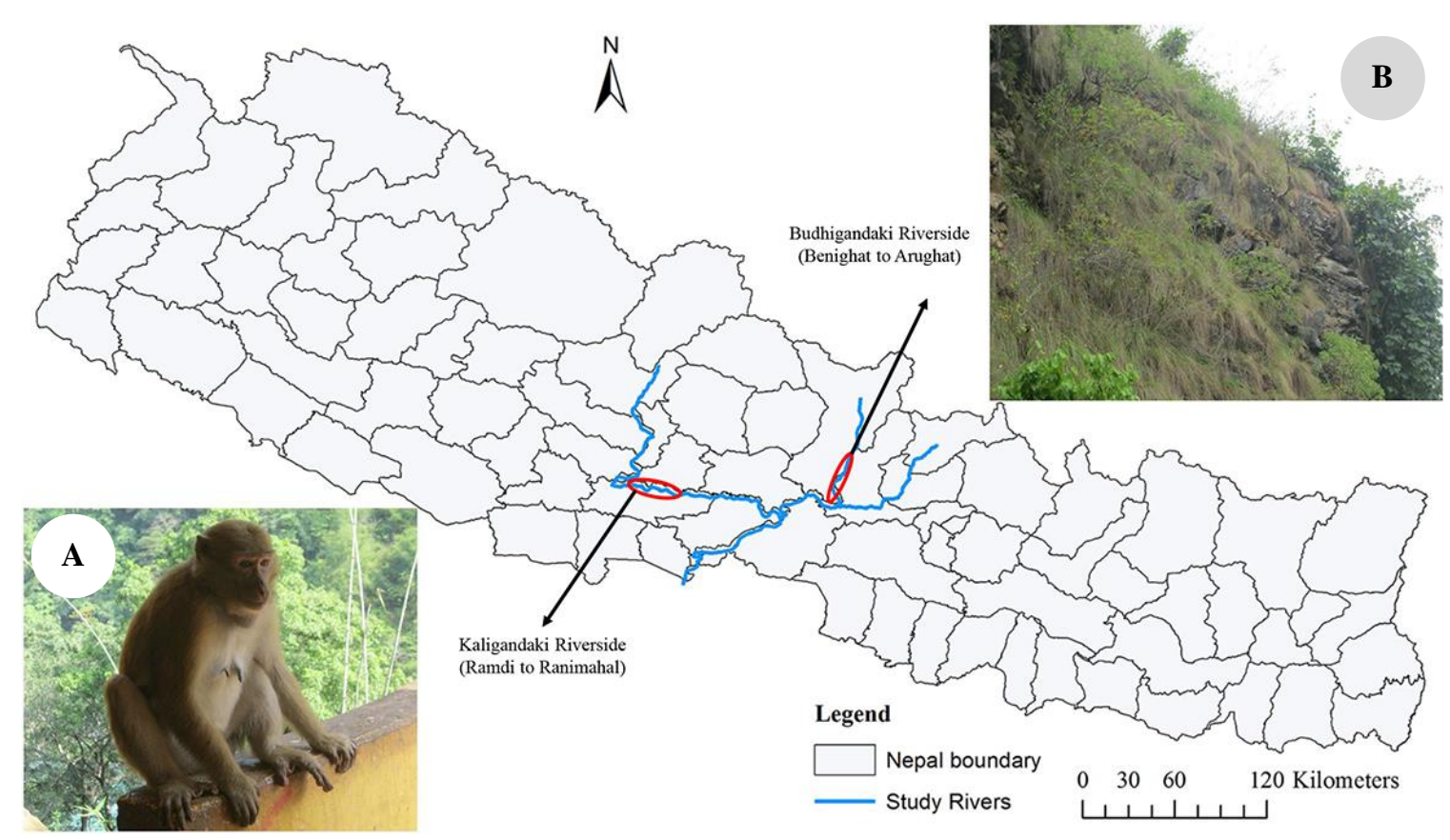

Figure 1. Map of Nepal indicating the study area (Kaligandaki and Budhigandaki River basins) in central Nepal. Photos in the inset indicate: A. An adult female Assamese macaque from KRBT; B. The BRBT troop resting on their resting site 


\section{Research troops, vegetation and behavioral survey}

Kaligandaki River Basin Troop (KRBT) inhabiting on Ramdi area in Syangja and Budhigandaki River Basin Troop (BRBT) inhabiting the Siurenitar area of the Gorkha district were studied as focal troops from the two river basins. The KRBT had a troop size of 18 individuals ( 3 adult males, 5 adult females, 3 young males, 2 young females and 5 infants) and the BRBT had 14 individuals (2 adult males, 4 adult females, 3 young males, 3 young females, 2 infants). Behavioral observations of each troop were made for 5 to 7 days each month. The same observer (SCG) observed KRBT and BRBT non-simultaneously for almost equal number of hours. The total observation time for the KRBT was 716 hours whereas the same for the BRBT was 691 hours. Behavioral data were recorded by the focal animal sampling method (Altmann 1974). The individuals of the focal troop of both the study area were identified with the help of different external characters and appearances such as facial features, skin color, cut marks, tail carriage, fur color and body structure.

The diurnal time was divided into four observational sessions, i.e. 06.00-09.00, 09.00-12.00, 12.00-15.00 and 15.00-18.00 hours. One adult focal animal was observed during each session continuously for 60 minutes and then switched to the next focal individual. All behavioral patterns of the focal animal and all behavior directed towards it by troop members were recorded. The choice of an individual was randomly determined among the adults prior to the observation. When the focal individual under observation was partially obscured or moved completely out of sight, the recording was stopped until it was visible again (Altmann 1974; Martin and Bateson 1993).

A total of 16 quadrates (total 32 quadrates for two troops) each of $20 \times 20 \mathrm{~m}^{2}$ were laid on the habitat of each study troop. The distance between the successive quadrates was maintained above $20 \mathrm{~m}$. All the trees within the quadrates were identified to the species level, counted and their diameter on breast height was measured at approximately $1.5 \mathrm{~m}$ above the ground. Data on the feeding behavior of Assamese macaques including food plants, food items and feeding time were collected by direct observation in the field following the methods as in Chalise et al. (2013). Different kinds of food plants and parts of plants, including young leaves, mature leaves, fruits, flowers, seeds, barks, and others, which the macaques ate, were noted in datasheet. The food species and plant parts were listed daily and a collective food list of Assamese macaque of each area was pooled.

\section{Data analysis}

All data were entered in Microsoft Excel and then analyzed primarily with descriptive statistics using the program Statistica for Windows release 7.0. Data on tree species from the vegetation survey were used to calculate the relative density and relative frequency of the trees.

$$
\begin{aligned}
& \text { Relative density }=\frac{\text { Density of the species }}{\text { Total density of all the species }} \times 100 \\
& \text { Relative freq. }=\frac{\text { Frequency values of the species }}{\text { Sum of frequency of all the species }} \times 100
\end{aligned}
$$

In order to calculate the similarity in food preference between the two study troops, Sorensen's Similarity Index $\left(\mathrm{S}_{\mathrm{s}}\right)$ was calculated as follows:

$$
S_{s}=\frac{2 a}{2 a+b+c}
$$

Where:

$\mathrm{S}_{\mathrm{s}}$ : Sorensen's similarity coefficient

a : Number of food plants in both communities (joint occurrences)

b : Number of food plants in KRBT but not in BRBT

c : Number of food plants in BRBT but not in KRBT

For overall behavioral data analysis, mean values among the focal animals of each troop were used for the monthly distribution of time spent on different behavioral states and events including feeding. Being specific to feeding, the time spent feeding different food plants and their parts were calculated and expressed in percentages. The difference in time investment in feeding specific plant parts between the two troops were tested for the significance by Kruskal-Wallis $\mathrm{H}$ test. The percentage time spent on particular food item was calculated as:

Percentage time spent on particular food item $=$

Total time spent on a particular food

Total time spent on feeding $\times 100$

\section{RESULTS AND DISCUSSION}

\section{Food items and feeding behavior}

Out of the total observation time (716 hours), the KRBT spent 294.7 hours $(41.16 \%)$ on feeding. Similarly, the BRBT was observed for 691 hours out of which, 306.5 hours $(44.36 \%)$ was invested in feeding. The highest percentage of time invested on feeding was in January and the least was in August for both the troops (Table 1).

The KRBT fed on 71 different plant species (45 tree species, 11 shrub species, 10 herb species and 5 climber species) and the BRBT fed on 69 plant species (43 tree species, 12 shrub species, 10 herb species and 4 climber species) (Table S1). Among them, 65 food plants were common between the sites that resulted in Sorensen's Similarity Index of 0.93. The trees like Trichilia connaroides dominated the habitat of the KRBT, Schima wallichii, Aegle marmelos, Ficus hispida, etc. whereas that of the BRBT was dominated by Shorea robusta, Adina cordifolia, Lagerstroemia parviflora, Spondias pinnata, etc. (Table 2). The KRBT used the leaf of Albizzia chinensis as their major food plant throughout the year, whereas BRBT used leaves of Lagerstroemia parviflora as a major food. The two troops had invested different percentage of time on feeding different plant parts (fruits, mature leaves, young leaves, seeds, flowers, barks, rhizomes) (Figure 2), however, Kruskal-Wallis $\mathrm{H}$ test $(\mathrm{H}=$ $0.3891, \mathrm{Hc}=0.3918, \mathrm{P}=0.5314$ ) revealed no significant difference on time investment between the two study troops. 


\section{Monthly variation of time spent on major food items}

Leaves (mature and young), fruits and seeds constituted the major food items (on which macaques invested longer time on feeding or they contributed larger amount of food) of Assamese macaques in both the study troops (Figure 3). The mean time spent for mature leaf-eating was $30.02 \%\left(\mathrm{~S}^{2}\right.$ $=389.6, \mathrm{CV}=65.7)$ per year by the KRBT and $29.04 \%\left(\mathrm{~S}^{2}\right.$ $=396.9, \mathrm{CV}=68.6)$ per year by the BRBT. The time spent for mature leaf-eating fluctuated between the months (Figure 3.A). Mature leaves were the major food items for macaques during the winter season (November-January), whereas, the same was less consumed during the spring season (March-May). The mean time spent for feeding young leaf was $19.56 \%\left(S^{2}=170.4, C V=66.7\right)$ per year by the KRBT and $20.70 \%\left(S^{2}=218.6, C V=71.4\right)$ per year by the BRBT. Consumption of young leaves was the highest during the spring and early summer (March-June) whereas the least during the winter season (Figure 3.B). In the spring season (March, April, and May), new young leaves emerged and were available to the macaques in higher amounts. After the rainy season, leaves become more mature, and in winter, defoliation starts.

Table 1. Monthly feeding time (\% of the total observation time) for KRBT and BRBT

\begin{tabular}{lcc}
\hline Month & KRBT (\%) & BRBT (\%) \\
\hline February 2015 & 52.61 & 56.42 \\
March & 55.23 & 57.64 \\
April & 32.65 & 34.96 \\
May & 31.46 & 33.83 \\
June & 34.33 & 38.71 \\
July & 30.54 & 34.33 \\
August & 24.45 & 25.92 \\
September & 32.42 & 34.22 \\
October & 42.12 & 46.26 \\
November & 48.11 & 54.72 \\
December & 53.64 & 57.12 \\
January 2016 & 56.34 & 58.18 \\
Mean (\%) & 41.16 & 44.36 \\
\hline
\end{tabular}

Table 2. Dominant 20 tree species of the Assamese macaque habitats in the study areas

\begin{tabular}{|c|c|c|c|c|c|}
\hline \multicolumn{3}{|c|}{ KRBT } & \multicolumn{3}{|c|}{ BRBT } \\
\hline Tree species & $\begin{array}{c}\text { Relative } \\
\text { density }\end{array}$ & $\begin{array}{c}\text { Relative } \\
\text { frequency }\end{array}$ & Tree species & $\begin{array}{c}\text { Relative } \\
\text { density }\end{array}$ & $\begin{array}{c}\text { Relative } \\
\text { frequency }\end{array}$ \\
\hline Trichilia connaroides & 35.68 & 8.38 & Shorea robusta & 29.75 & 8.87 \\
\hline Schima wallichii & 18.76 & 6.58 & Adina cordifolia & 12.82 & 6.50 \\
\hline Aegle marmelos & 9.79 & 5.38 & Lagerstroemia parviflora & 8.12 & 4.73 \\
\hline Ficus hispida & 8.51 & 4.79 & Spondias pinnata & 5.98 & 4.73 \\
\hline Albizzia chinensis & 7.65 & 4.79 & Terminalia alata & 3.41 & 4.14 \\
\hline Madhuca longifolia & 6.53 & 4.19 & Phyllanthus emblica & 3.41 & 4.14 \\
\hline Aporosa octandra & 6.36 & 4.19 & Mallotus philippensis & 3.16 & 4.14 \\
\hline Toona ciliata & 5.59 & 4.19 & Schima wallichii & 3.06 & 4.14 \\
\hline Semecarpus anacardium & 3.96 & 3.59 & Albizzia chinensis & 2.90 & 4.14 \\
\hline Ficus hederacea & 3.82 & 3.59 & Aporosa octandra & 2.53 & 3.55 \\
\hline Lannea coromandelica & 3.45 & 3.59 & Madhuca longifolia & 2.39 & 3.55 \\
\hline Butea minor & 2.36 & 3.59 & Trichilia connaroides & 2.39 & 3.55 \\
\hline Uraria lagopodioides & 1.98 & 3.59 & Toona ciliata & 1.96 & 3.55 \\
\hline Acacia catechu & 1.98 & 3.59 & Butea minor & 1.59 & 3.55 \\
\hline Terminalia bellirica & 1.63 & 2.99 & Acacia catechu & 1.45 & 2.95 \\
\hline Lagerstroemia parviflora & 1.63 & 2.99 & Ficus hederacea & 1.33 & 2.95 \\
\hline Hymenodictyon excelsum & 1.45 & 2.39 & Terminalia bellirica & 1.33 & 2.95 \\
\hline Castanopsis indica & 1.45 & 2.39 & Sapindus mukorossi & 1.19 & 2.36 \\
\hline Erythrina variegata & 1.45 & 2.39 & Terminalia chebula & 1.19 & 2.36 \\
\hline Sapindus mukorossi & 1.04 & 1.79 & Erythrina variegata & 1.19 & 2.36 \\
\hline
\end{tabular}

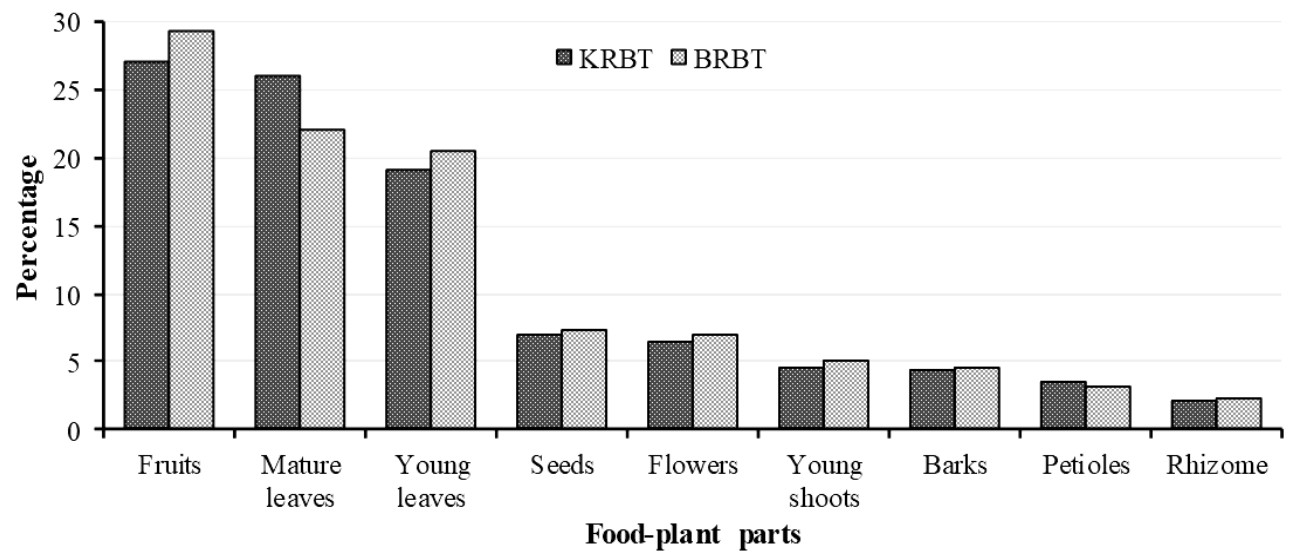

Figure 2. Percentage of time invested on different food-plant parts by the KRBT and BRBT of Assamese macaques (Based on Table S1) 
Fruits are a patchy and clumped seasonal resource available in lower density than leaves in the study area. The mean time spent for fruit-eating was $23.80 \%\left(\mathrm{~S}^{2}=226.5\right.$, $\mathrm{CV}=63.2)$ per year by KRBT and $25.96 \%\left(\mathrm{~S}^{2}=195.3, \mathrm{CV}\right.$ = 53.8) per year by BRBT (Figure 3.C). Availability of fruits, and hence their consumptions were higher during the early monsoon and winter seasons. The time spent on fruits had two peaks and two faults in a year (Figure 3.C). JuneJuly and November-December were the rising peaks while August-September and January-April were falling faults whereas May and October had contributed near an average time spent for fruits. Seeds were another major food item for the macaques. The mean time spent for seed-eating was $2.71 \%\left(\mathrm{~S}^{2}=5.8, \mathrm{CV}=88.5\right)$ per year by the KRBT and $2.07 \%\left(\mathrm{~S}^{2}=3.6, \mathrm{CV}=92.2\right)$ per year by the BRBT (Figure 3.D). The seed-eating time percentage was higher during the spring season (March, April), and the time spent was lesser in the months of the beginning of the winter season (November, December) in both study areas.

\section{Monthly variation of time spent on feeding accessory plant parts}

The accessory plant parts that formed the component of Assamese macaque food were young shoots, barks, flowers, and petioles (Figure 4). The mean time spent for young shoot eating was $2.00 \%\left(\mathrm{~S}^{2}=4.4, \mathrm{CV}=105.3\right)$ per year by the KRBT and $1.50 \%\left(\mathrm{~S}^{2}=1.1, \mathrm{CV}=69.2\right)$ per year by the BRBT. The consumption o young shoot peaked twice in a year, once during the late spring and the next during the autumn (Figure 4.A). The average time spent on eating flowers over the year was $0.95 \%\left(\mathrm{~S}^{2}=1.1, \mathrm{CV}=\right.$ $112.8)$ for the KRBT and $0.85 \%\left(S^{2}=0.6, C V=92.8\right)$ for the BRBT. A high peak of the abundance of flower was during the spring season (March and April) and concordance to this the time spent on flowers was highest in April (03.86\% for the KRBT and $02.81 \%$ for BRBT).

The KRBT spent an average $0.12 \%\left(\mathrm{~S}^{2}=0.0, \mathrm{CV}=\right.$ 88.4 ) while the BRBT spent average $0.22 \%\left(\mathrm{~S}^{2}=0.1, \mathrm{CV}=\right.$ 104.6) of annual time on bark eating over the year. There was no distinct seasonal pattern on barks consumption. The mean time spent for petiole eating was $0.36 \%\left(\mathrm{~S}^{2}=0.1, \mathrm{CV}\right.$ $=93.5)$ per year by the KRBT and $0.42 \%\left(S^{2}=0.1, \mathrm{CV}=\right.$ 67.7) per year by the BRBT. Petiole consumption peaked during the spring season.
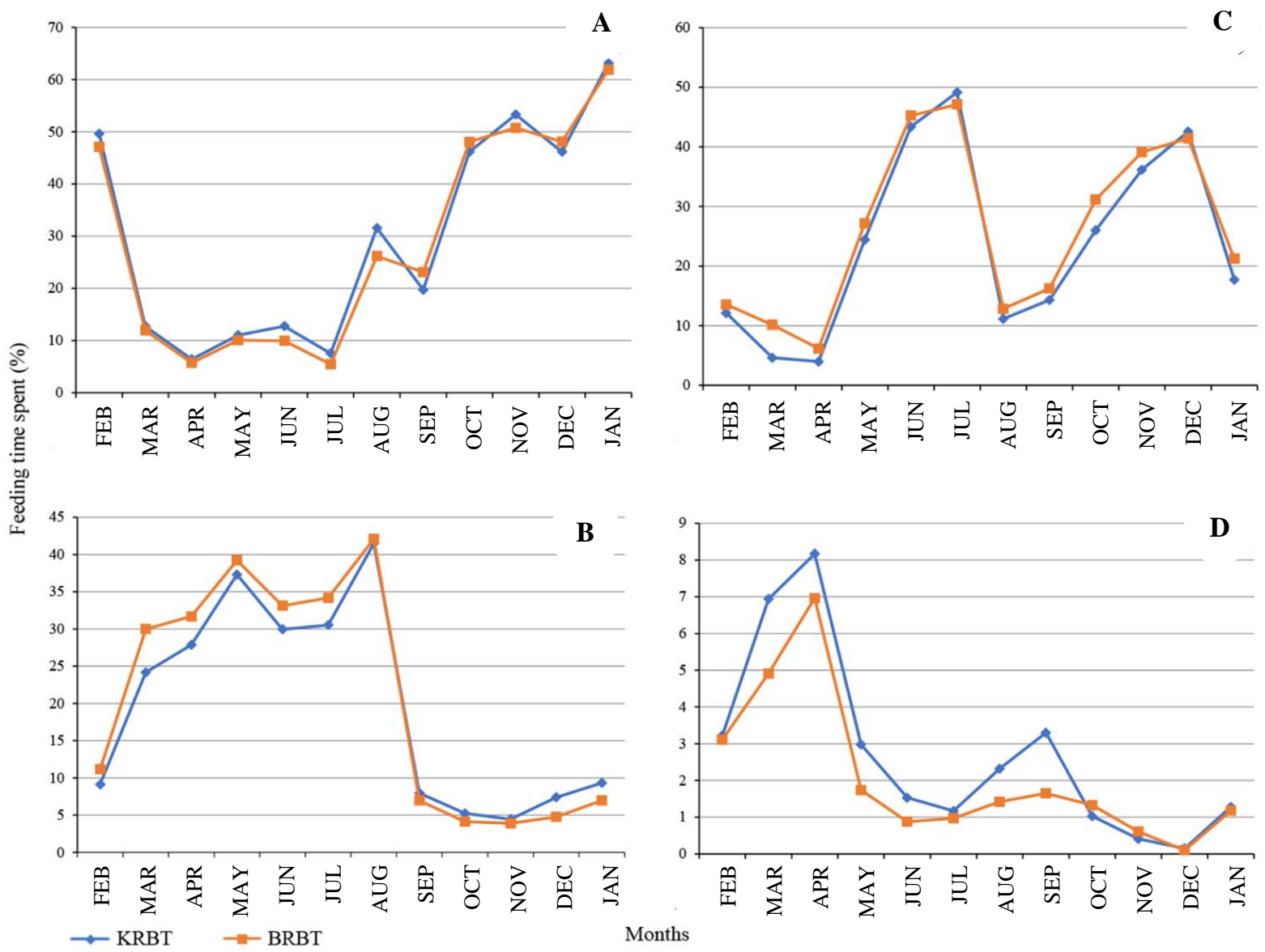

Figure 3. Monthly variation in time spent on feeding major food items by two study troops (KRBT and BRBT) of Assamese macaques; A. Mature leaves, B. Young leaves, C. Fruits, and D. Seeds. 


\section{Monthly variation of time spent on other food items}

Apart from the aerial plant parts, Assamese macaques were observed consuming other food items, including the rhizome, invertebrates, licking on stone and soil eating (geophagy) (Figure 5). The average time spent on rhizome eating over the year was $0.73 \%\left(\mathrm{~S}^{2}=0.5, \mathrm{CV}=100.5\right)$ for the KRBT and $1.02 \%\left(\mathrm{~S}^{2}=0.8, \mathrm{CV}=87.1\right)$ for the BRBT. The highest time spent on rhizome eating was recorded during the spring season for both the study troops.

Invertebrates were foraged with an average time of $2.90 \%\left(S^{2}=20.4, C V=155.8\right)$ per year by the KRBT and $2.43 \%\left(S^{2}=11.6, C V=139.9\right)$ per year by the BRBT. The invertebrate-eating peak time was observed during February and March. Additionally, stone licking and geophagy were the remarkable phenomena of eating inorganic foods observed in both the study troops which licked stones in the sides of both the rivers (Kaligandaki and Budhigandaki). The mean time spent for stone licking was $2.04 \%\left(\mathrm{~S}^{2}=5.5, \mathrm{CV}=115.3\right)$ per year by the KRBT and $1.40 \%\left(\mathrm{~S}^{2}=3.9, \mathrm{CV}=141.3\right)$ per year by the BRBT. Stone licking was consistently higher in KRBT than the BRBT except for August. The mean time spent for geophagy was $0.55 \%\left(\mathrm{~S}^{2}=0.3, \mathrm{CV}=92.5\right)$ per year by the KRBT and $0.33 \%\left(\mathrm{~S}^{2}=0.1, \mathrm{CV}=83.9\right)$ per year by the BRBT. Soil eating was highest during March at $01.95 \%$ for Kaligandaki while during September at $00.95 \%$ for Budhigandaki.

Apart from plant parts consumption and geophagy, both the troops of Assamese macaques were observed drinking water and occasionally feeding on the wastes. The mean time spent for water drinking was $0.99 \%\left(\mathrm{~S}^{2}=0.8, \mathrm{CV}=\right.$ 90.1) per year by KRBT and $0.90 \%\left(S^{2}=0.7, C V=90.5\right)$ per year by BRBT. The average time spent for waste eating was $0.21 \%\left(\mathrm{~S}^{2}=0.1, \mathrm{CV}=129.5\right)$ per year by the KRBT and $0.13 \%\left(S^{2}=0.0, C V=85.9\right)$ per year by the BRBT.
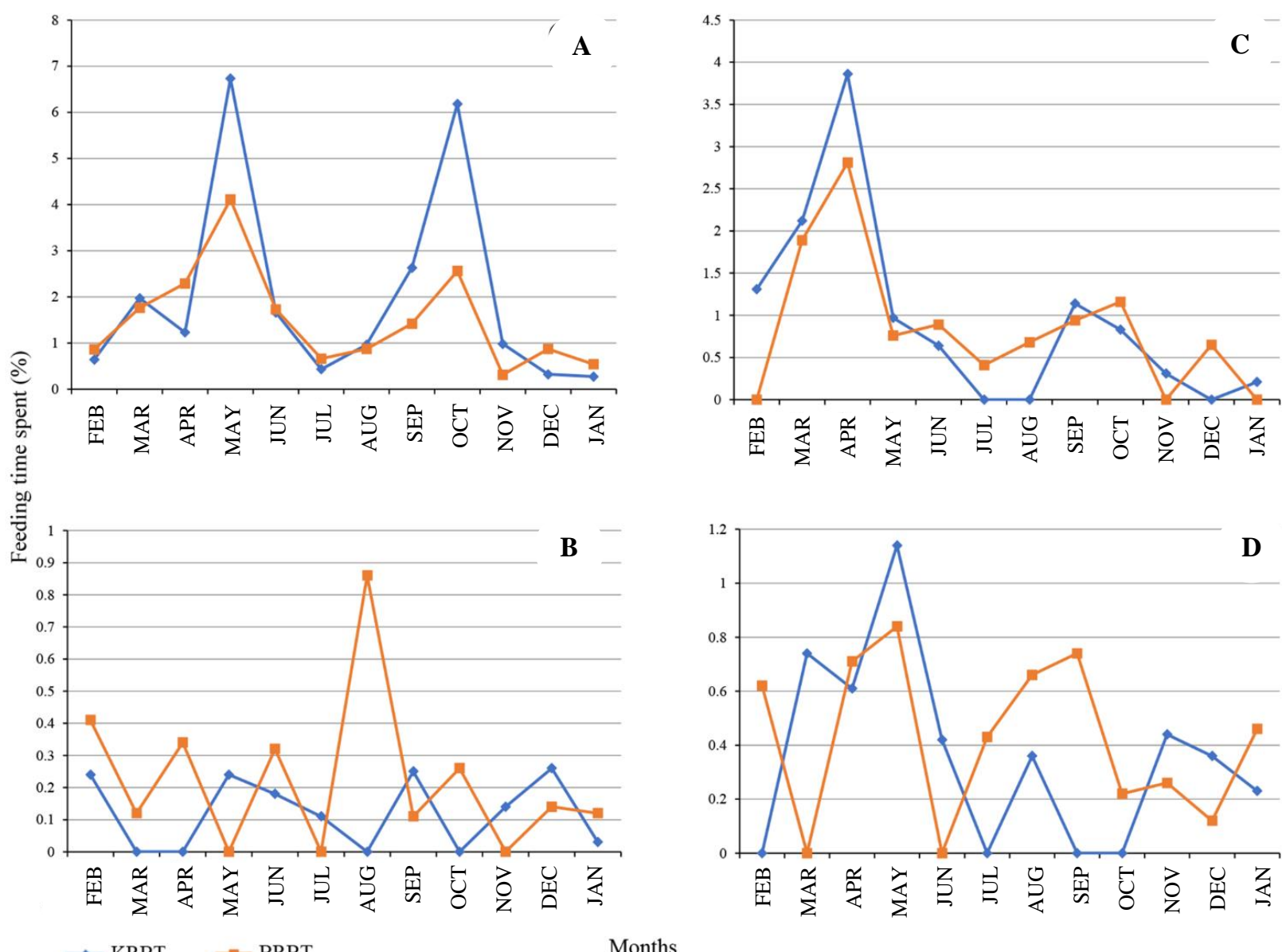

Figure 4. Monthly variation in time spent on feeding accessory plant parts by two study troops (KRBT and BRBT) of Assamese macaques; A. Young shoots, B. Barks, C. Flowers, D. Petioles 

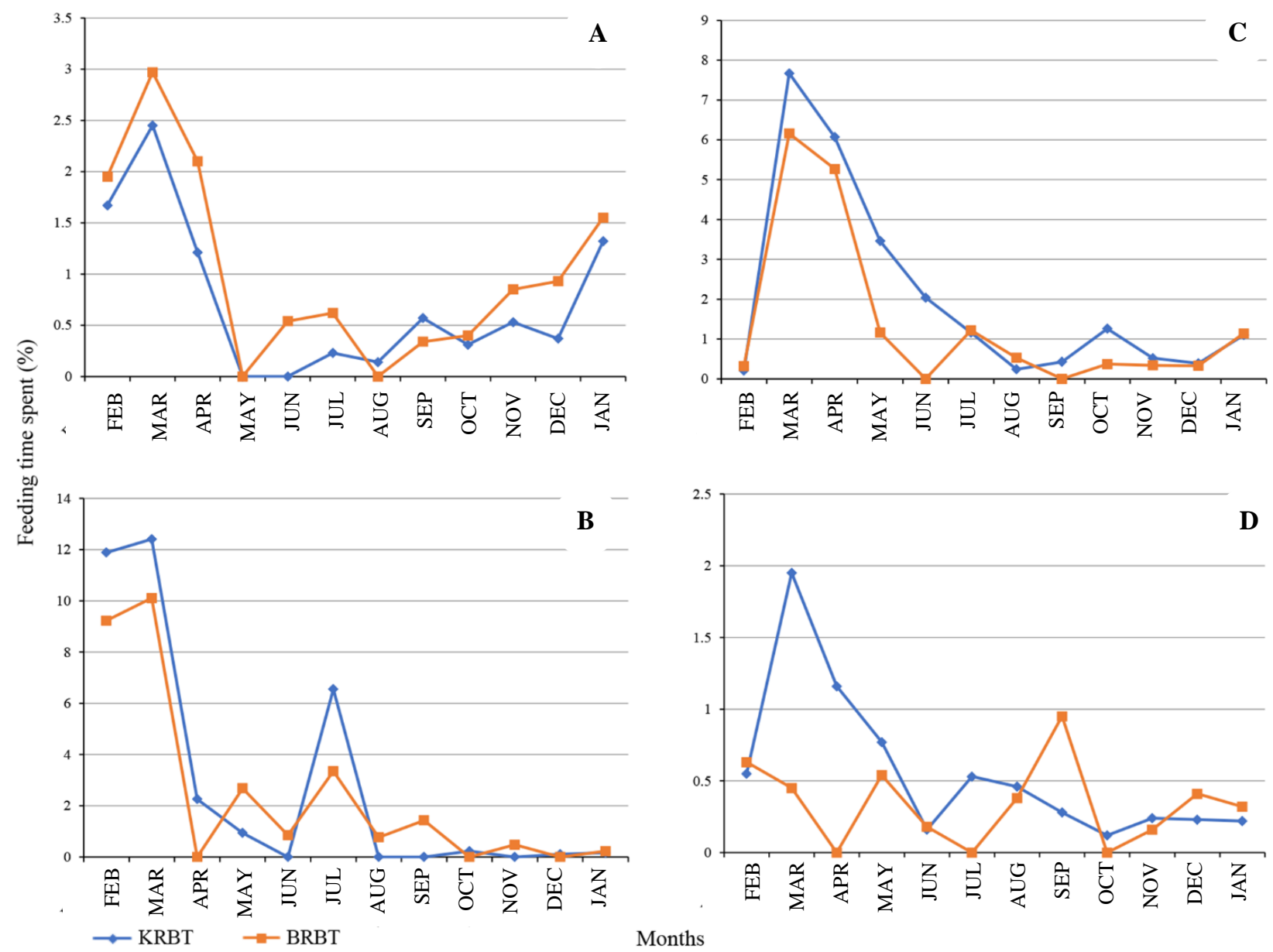

Figure 5. Monthly variation in time spent on accessory food items by two study troops (KRBT and BRBT) of Assamese macaques; A. Rhizome, B. Invertebrates, C. Stone licking, D. Soil eating (geophagy)

\section{Discussion}

Assamese macaques in central Nepal invested majority ( $>40 \%$ on average) of their diurnal time on feeding. They devoted more than half of the diurnal time to feeding and foraging during the winter months (December-February) when resources were limited in cold and dry periods. There appears to be a strong seasonality in the availability of food resources in the area, and macaques show plasticity in selecting the food items according to their availability. Similar to our findings, Assamese monkeys in Nonggang Nature Reserve, China spend a greater proportion of time on feeding and less time on resting and grooming in the dry season than in the rainy season (Zhou et al. 2007). Monkeys feed on low-quality, subsistence foods, such as mature leaves, when high-quality foods, such as fruits and young leaves are scarce (Zhou et al. 2006).

Assamese macaques in the study area depicted food specialist nature showing their higher dependence on the less dominant food plants of the habitat. The dominant plants of the habitat were not always the first choice of food for Assamese macaques. The habitat of the KRBT was dominated by the plants like Trichilia connaroides, Schima wallichii, Aegle marmelos, etc., however, the most consumed plant parts were from relatively less abundant
Albizzia chinensis. The BRBT inhabits the area of higher abundance of Shorea robusta, Adina cordifolia, Lagerstroemia parviflora, etc. and the species third in the rank was the most preferred food plant. Among the different plant parts, leaves formed the major bulk in the diet of Assamese macaques. Although described as omnivorous (Boonaratana et al. 2020), they are primarily dependent upon leaves, fruits and seeds.

The observations on feeding habits revealed that Assamese macaques are adaptable foragers able to modify their diet seasonally, being more folivorous in the dry season and more frugivorous in the wet season. Due to the seasonal variation on availability of different food items, the Assamese macaques had to shift their preference for major food items seasonally. In highly seasonal habitats, food availability is not even over the year, and species cannot rely entirely on preferred foods. Instead, they are expected to include less preferred fallback foods in their diet during a certain period of the year (Marshall and Wrangham 2007). Therefore, it is expected that omnivorous species tune their feeding patterns to seasonal resource availability. Furthermore, climate change is predicted to have significant effects on plant phenology and vegetation structure (Chapman et al. 2005). The seasonal 
pattern of fruit production sometimes becomes more important than habitat characteristics in determining the diet of primates (Dunn et al. 2010). Seasonal variation in the diet of Assamese macaques was clearly linked to seasonal fluctuation in food availability. For example, they relied heavily on young leaves during the spring season during which consumption of the mature leaves dropped. Such a relationship has been widely demonstrated in primates (Simmen et al. 2003; Norsica et al. 2006). Animals that live in seasonally changing environments concentrate on specific food sources that are available all year round or vary their diet in relation to seasonal changes in availability (Guo et al. 2007).

Assamese macaques are mostly folivores, and the time spent on leaf-eating (mature and young) was nearly half (49.58\% in KRBT and $49.74 \%$ in BRBT) of their total feeding time. Similar to our findings, young leaves were stapled food items for Assamese macaques inhabiting limestone forests in Nonggang, China, which constituted the bulk of monthly diets almost yearly (Zhou et al. 2011; Huang et al. 2015). There was no significant difference in time investment on different food items between the KRBT and BRBT of Assamese macaques. Koirala et al. (2017) observed significant difference in feeding time investment and diurnal activity pattern between two troops of Assamese macaques, one of which was wild and the other was partially supplemented waste foods. Adhikari et al. (2018) also observed significant alteration in the behavior of a troop of Assamese macaque supplemented human food. Both the troops of this study are in a similar ecological set up of deciduous rainforest and also have highly similar food plant preferences, which might have caused almost similar investment of time on feeding and food selection.

Among other food items apart from leaves, the amount of time invested on fruits, flowers, and seeds was high. It suggests that Assamese macaques like to avoid leaves (especially mature) and try to intake other more nutritive food whenever possible. The species in Thailand has been reported to invest the largest part of feeding time $(42.4 \%)$ on fruits (Schulke et al. 2011). In Nonggang Nature Reserve, China, Assamese macaques invested less than $20 \%$ time on feeding fruits, suggesting their folivorous habits (Zhou et al. 2011; Huang et al. 2015). Some primates eat barks during the dry season when the least amount of food is available, providing food with water (Sugiyama 1964). Bark assumed leading importance in the diet of Bornean orangutans when major fruits did not ripen (Nishida 1976). Bark eating was recorded in Assamese macaques when young leaves and fruits were undersupplied. It suggests that Assamese macaques utilize bark as food whenever other foods are less abundant.

The availability of food in the deciduous forests of Kaligandaki River Basin and Budhigandaki River Basin is highly seasonal. The effect of such seasonality on food availability is reflected in the feeding behavior of Assamese macaques. Food distribution determines search strategies and animal movement patterns that in turn affect the time investment on feeding (Reyna-Hurtado et al. 2018). Species that experience large and unpredictable seasonal variations in food availability tend to grow and reproduce at slower rates than species with more predictable environments (Wright et al. 2015). During the scarcity of high-energy foods, animals reduce most energydemanding activities, travel less and over shorter distances, but use their home range more broadly (Nagy-Reis and Setz 2017). Similar to these observations, Assamese macaques in central Nepal switched between the young leaves and mature leaves according to their availability, but the higher preference was to the young leaves.

In conclusion, the Assamese macaques of Kaligandaki and Budhigandaki river basins contributed to leaf-eating, followed by fruits and seeds. Assamese macaques in Kaligandaki River Basin frequently utilized leaves of Albizzia chinensis and that of Budhigandaki River Basin chose leaves of Lagerstroemia parviflora as their major food plant throughout the year. This indicates that Assamese macaques of both river basins are mostly folivorous. Food choice and time investment on the feeding of different plant parts may differ depending on the food availability in the area. Macaques living in the wild at comparable ecological setups with similar nutrient concentrations of staple foods have analogous food choices and time investments.

\section{ACKNOWLEDGEMENTS}

We are thankful to the Department of National Parks and Wildlife Conservation, Department of Forest and Soil Conservation, Ministry of Forest and Environment, Government of Nepal, to grant study permission. Our sincere thanks go to our field assistants, helpers, and local villagers of Kaligandaki and Budhigandaki for their kind co-operation during the fieldwork. We express sincere thanks to Dr. Vikash Raj Satyal, Amrit Science Campus, Tribhuvan University, Kathmandu for data analysis support and Rajesh Tandukar for manuscript preparation.

\section{REFERENCES}

Adhikari K, Khanal L, Chalise MK. 2018. Status and effects of food provisioning on ecology of Assamese monkey (Macaca assamensis) in Ramdi area of Palpa, Nepal. J Inst Sci Tech 22 (2): 183-190. DOI: 10.3126/jist.v22i2.19611.

Altmann J. 1974. Observational study of behavior: sampling methods. Behaviour 49 (3-4): 227-266. DOI: 10.1163/156853974X00534.

Bessa J, Sousa C, Hockings KJ. 2015. Feeding ecology of chimpanzees (Pan troglodytes verus) inhabiting a forest-mangrove-savannaagricultural matrix at Caiquene-Cadique, Cantanhez National Park, $\begin{array}{lllll}\text { Guinea-Bissau. Am J Primatol } 77 \text { (6): 651-665. } & \end{array}$ DOI:10.1002/ajp.22388

Boonratana R, Chalise MK, Das J, Htun S, Timmins RJ. 2020. The IUCN Red List of Threatened https://www.iucn.org/theme/species/our-work/iucn-red-listthreatened-species.

Cabana F, Dierenfeld E, Wirdateti W, Donati G, Nekaris KAI. 2017. The seasonal feeding ecology of the Javan slow loris (Nycticebus javanicus). Am J Phys Anthropol 162 (4): 768-781. DOI: 10.1002/ajpa.23168.

Chalise MK. 2003. Assamese macaques (Macaca assamensis) in Nepal. Primate Conserv 19: 99-107.

Chalise MK. 2008. Primate census in Kathmandu and west parts of Nepal. J Nat Hist Mus 23: 60-64. DOI: 10.3126/jnhm.v23i0.1840. 
Chalise MK. 2010. A study of Assamese monkey in Sebrubeshi of Langtang National Park, Nepal. J Nat Hist Mus 25: 54-61.

Chalise MK. 2013. Fragmented primate population of Nepal. In: Marsh LK, Chapman CA (eds) Primates in Fragments: Complexity and Resilience. Springer Science+Business Media, New York 329-356. DOI: 10.1007/978-1-4614-8839-2_22.

Chalise MK, Bhattarai GP, Pandey B. 2013. Ecology and behavior of Assamese monkeys in Shivapuri Nagarjun National Park, Nepal. J Nat Hist Mus 27: 12-24. DOI: 10.3126/jnhm.v27i0.14149.

Chapman CA, Chapman LJ, Wrangham RW. 1995. Ecological constraints on group size: an analysis of spider monkey and chimpanzee subgroups. Behav Ecol Sociobiol 36 (1): 59-70. DOI: 10.1007/BF00175729.

Chapman CA, Chapman LJ, Struhsaker TT, Zanne AE, Clark CJ, Poulsen JR. 2005. A long-term evaluation of fruiting phenology: importance of climate change. J Trop Ecol 21: 31-45. DOI: 10.1017/S0266467404001993.

Clink DJ, Dillis C, Feilen KL, Beaudrot L, Marshall AJ. 2017. Dietary diversity, feeding selectivity, and responses to fruit scarcity of two sympatric Bornean primates (Hylobates albibarbis and Presbytis rubicunda rubida). PloS One 12 (3), e0173369. DOI: 10.1371/journal.pone.0173369.

Davies AG, Bennett EL, Waterman PG. 1988. Food selection by two Southeast Asian colobine monkeys (Presbytis rubicunda and Presbytis melalophos) in relation to plant chemistry. Biol J Linn Soc 34 (1): 33-56. DOI: 10.1111/j.1095-8312.1988.tb01947.x.

Dunn JC, Cristobal-Azkarate J, Vea JJ. 2010. Seasonal variations in the diet and feeding effort of two groups of Howlers in different sized forest fragments. Int J Primatol 31: 887-903. DOI: 10.1007/s10764010-9436-0.

Frechette JL, Hon N, Behie A, Rawson BM. 2017. Seasonal variation in the diet and activity budget of the northern yellow-cheeked crested gibbon Nomascus annamensis. Cambodian J Nat Hist 2: 168-178.

Ghimire SC, Chalise MK. 2018. Status of crop raiding by Assamese monkeys (Macaca assamensis) along the Budhigandaki river, central Nepal. J Nat Hist Mus 30: 294-305. DOI: 10.3126/jnhm.v30i0.27605.

Ghimire SC, Chalise MK. 2019. Crop raiding status by Assamese monkeys (Macaca assamensis) along the Kaligandaki River, western Nepal. J Ins Sci Tech 24 (1): 72-76. DOI: 10.3126/jist. v24i1.24639.

Grueter CC. 2017. Environmental seasonality. The international encyclopedia of primatology 1-2. DOI 10.1002/9781119179313.wbprim0048.

Guo S, Li B, Watanabe K. 2007. Diet and activity budget of Rhinopithecus roxellana in the Qinling Mountains, China. Primates 48: 268-276. DOI: 10.1007/s10329-007-0048-z.

Hemingway CA, Bynum N. 2005. The influence of seasonality on primate diet and ranging. In: Brockman DK, van Schaik CP (eds). Seasonality in primates: Studies of living and extinct human and non-human primates. Cambridge University Press, United Kingdom.

Huang Z, Huang C, Tang C, Huang L, Tang H, Ma G, Zhou, Q. 2015. Dietary adaptations of Assamese macaques (Macaca assamensis) in limestone forests in southwest China. Am J Primatol 77 (2): 171-185. DOI: $10.1002 /$ ajp. 22320.

Kaplin BA, Munyaligoga V, Moermond TC. 1998. The influence of temporal changes in fruit availability on diet composition and seed handling in Blue Monkeys (Cercopithecus mitis doggetti). Biotropica 30 (1): 56-71. DOI: 10.1111/j.1744-7429.1998.tb00369.x.

Khanal L, Chalise MK, He K, Acharya BK, Kawamoto Y, Jiang X. 2018. Mitochondrial DNA analyses and ecological niche modeling reveal post-LGM expansion of the Assam macaque (Macaca assamensis) in the foothills of Nepal Himalaya. Am J Primatol 80 (3): e22748. DOI: 10.1002/ajp.22748

Khanal L, Chalise MK, Jiang, XL. 2019. Distribution of the threatened Assamese Macaque Macaca assamensis (Mammalia: Primates: Cercopithecidae) population in Nepal. J Threat Taxa 11 (1): $13047-$ 13057. DOI: 10.11609/jott.4623.11.1.13047-13057.

Khanal L, Chalise MK, Fan PF, Kyes RC, Jiang XL. 2021. Multilocus phylogeny suggests a distinct species status for the Nepal population of Assam macaques (Macaca assamensis): implications for evolution and conservation. Zool Res 42 (1): 3-13. DOI: 10.24272/j.issn.20958137.2020.279.

Knott CD. 2005. Energetic responses to food availability in the great apes: implications for hominin evolution. In: Brockman DK, van Schaik CP (eds). Seasonality in Primates: Studies of Living and Extinct Human and Non-Human Primates 44: 351-378. Cambridge University Press

Koirala, S, Chalise, MK, Katuwal, HB, Gaire, R, Pandey, B, Ogawa, H. 2017. Diet and activity of Macaca assamensis in wild and semiprovisioned groups in Shivapuri Nagarjun National Park, Nepal. Folia Primatol 88 (2): 57-74. DOI:10.1159/000477581

Majolo B, McFarland R, Young C, Qarro M. 2013. The effect of climatic factors on the activity budgets of Barbary macaques (Macaca sylvanus). Int J Primatol 34 (3): 500-514. DOI: 10.1007/s10764-0139678-8.

Marshall AJ, Wrangham RW. 2007. Evolutionary consequences of fallback foods. Int J Primatol 28: 1219-1235. DOI: 10.1007/s10764007-9218-5.

Martin P, Bateson P. 1993. Measuring behaviour: An introductory guide. Cambridge University Press. DOI: 10.1017/9781108776462.

McFarland R, Barrett L, Boner R, Freeman NJ, Henzi SP. 2014. Behavioral flexibility of vervet monkeys in response to climatic and social variability. Am J Phys Anthropol 154 (3): 357-364. DOI: 10.1002/ajpa.22518.

McLennan MR, Spagnoletti N, Hockings KJ. 2017. The implications of primate behavioral flexibility for sustainable human-primate coexistence in anthropogenic habitats. Int J Primatol 38 (2): 105-121. DOI:10.1007/s10764-017-9962-0.

Ni Q, Xie M, Grueter CC, Jiang X, Xu H, Yao Y, Zhang M, Li Y, Yang J. 2015. Effects of food availability and climate on activity patterns of western black-crested gibbons in an isolated forest fragment in southern Yunnan, China. Primates 56 (4): 351-363. DOI: 10.1007/s10329-015-0481-3.

Nishida T. 1976. The bark-eating habits in primates, with special reference to their status in the diet of wild chimpanzees. Folia Primatol 25 (4): 277-287. DOI: 10.1159/000155720.

Norsica I, Carrai V, Borgognini-Tarli SM. 2006. Influence of dry season and food quality and quantity on behavior and feeding strategy of Propithecus verreauxi in Kirindy, Madagascar. Int J Primatol 27: 1001-1022. DOI: 10.1007/s10764-006-9056-x.

Paudel PK. 2017. Conflict due to Assamese macaques (Macaca assamensis McClelland, 1840) and crop protection strategies in Kaligandaki river basin, western Nepal. Our Nature 14 (1): 107. DOI: 10.3126/on.v14i1.16449.

Reyna-Hurtado R, Teichroeb JA, Bonnell TR, Hernández-Sarabia RU, Vickers SM, Serio-Silva JC, et al. 2018. Primates adjust movement strategies due to changing food availability. Behav Ecol 29 (2): 368376. DOI: 10.1093/beheco/arx176.

Schülke O, Pesek D, Whitman BJ, Ostner J. 2011. Ecology of Assamese macaques (Macaca assamensis) at Phu Khieo Wildlife Sanctuary, Thailand. J Wildlife Thai 18 (1): 1-15.

Serckx A, Kühl HS, Beudels-Jamar RC, Poncin P, Bastin JF, Huynen MC. 2015. Feeding ecology of bonobos living in forest-savannah mosaics: Diet seasonal variation and importance of fallback foods. Am J Primatol 77 (9): 948-962. DOI: 10.1002/ajp.22425.

Simmen B, Hladik A, Ramasirisoa P. 2003. Food intake and dietary overlap in native Lemur catta and Propithecus verreauxi and introduced Eulemur fulvus at Berenty, southern Madagascar. Int J Primatol 24: 949-968. DOI: 10.1023/A:1026366309980.

Sugiyama Y. 1964. Group composition, population density and some sociological observations of hanuman langurs. Primates 5 (3-4): 7-37. DOI: $10.1007 / \mathrm{BF} 01791642$.

Wright E, Grueter CC, Seiler N, Abavandimwe D, Stoinski TS, Ortmann S, et al. 2015. Energetic responses to variation in food availability in the two mountain gorilla populations (Gorilla beringei beringei). Am J Phys Anthropol 158 (3): 487-500. DOI: 10.1002/ajpa.22808.

Zhou, Q, Wei, F, Li, M, Huang, C, Luo, B. 2006. Diet and food choice of Trachypithecus francoisi in the Nonggang Nature Reserve, China. Int J Primatol 27 (5): 1441-1460. DOI:10.1007/s10764-006-9082-8.

Zhou Q, Wei F, Huang C, Li M, Ren B, Luo, B. 2007. Seasonal variation in the activity patterns and time budgets of Trachypithecus francoisi in the Nonggang Nature Reserve, China. Intl J Primatol 28 (3): 657671. doi:10.1007/s10764-007-9144-6.

Zhou Q, Wei H, Huang Z, Huang C. 2011. Diet of the Assamese macaque Macaca assamensis in lime-stone habitats of Nonggang, China. Curr Zool 57 (1): 18-25. DOI: 10.1093/czoolo/57.1.18. 
Table S1. List of food plants and their parts used by Assamese macaque troops

\begin{tabular}{|c|c|c|c|}
\hline & RBT & \multicolumn{2}{|c|}{ BRBT } \\
\hline Scientific name & Part used as food & Scientific name & Part used as food \\
\hline Acacia catechu & Mature leaf & Acacia catechu & Mature leaf \\
\hline Aegle marmelos & Fruit & Adina cardifolia & Young leaf \\
\hline Albizzia chinensis & Mature leaf, young leaf & Aegle marmelos & Fruit \\
\hline Alstonia scholaries & Young leaf & Albizzia chinensis & Mature leaf, young leaf \\
\hline Anthocephalus chinensis & Young leaf, flower & Alstonia scholaries & Young leaf \\
\hline Antidesma acidum & Mature leaf & Anthocephalus chinensis & Young leaf, flower \\
\hline Antidesma ghaesembilla & Mature leaf & Antidesma acidum & Mature leaf \\
\hline Aporusa octandra & Young leaf, flower & Aporusa octandra & Young leaf, flower \\
\hline Ardisia solanacea & Fruit & Ardisia solanacea & Fruit \\
\hline Arisaema tortuosum & Seed & Arisaema tortuosum & Seed \\
\hline Arundinaria intermedia & Young shoot & Arundinaria intermedia & Young shoot \\
\hline Bauhinia purpurea & Fruit, young shoot & Bauhinia purpurea & Fruit, young shoot \\
\hline Bauhinia vahlii & Seed & Bauhinia vahlii & Seed \\
\hline Bauhinia variegata & Flower, bark & Bauhinia variegata & Flower, bark \\
\hline Begonia picta & Mature leaf & Berberis asiatica & Fruit \\
\hline Berberis asiatica & Fruit & Bombax ceiba & Young leaf \\
\hline Bombax ceiba & Young leaf & Callicarpa arborea & Mature leaf \\
\hline Callicarpa arborea & Mature leaf & Castanopsis indica & Seed \\
\hline Castanopsis indica & Seed & Castanopsis tribuloides & Seed \\
\hline Castanopsis tribuloides & Seed & Colebrookea oppositifolia & Flower \\
\hline Colebrookea oppositifolia & Flower & Colocasium esculenta & Young leaf \\
\hline Colocasium esculenta & Young leaf & Cynodon dactylon & Mature leaf \\
\hline Cynodon dactylon & Mature leaf & Dendrocalamus strictus & Young shoot \\
\hline Dendrocalamus strictus & Young shoot & Dioscorea bulbifera & Rhizome, young leaf, petiole \\
\hline Dioscorea bulbifera & Rhizome, young leaf, petiole & Diploknema butyracea & Fruit \\
\hline Diploknema butyracea & Fruit & Dryopteris filix-mas & Mature leaf \\
\hline Dryopteris filix-mas & Mature leaf & Eupatorium odoratum & Young leaf, petiole \\
\hline Eupatorium odoratum & Young leaf, petiole & Ficus benghalensis & Fruit \\
\hline Ficus benghalensis & Fruit & Ficus benjamina & Fruit \\
\hline Ficus benjamina & Fruit & Ficus hispida & Fruit, bark \\
\hline Ficus hispida & Fruit, bark & Ficus lacor & Young leaf \\
\hline Ficus lacor & Young leaf & Ficus nervosa & Young leaf \\
\hline Ficus nervosa & Young leaf & Ficus racemose & Young leaf \\
\hline Ficus racemose & Young leaf & Ficus religiosa & Fruit \\
\hline Ficus religiosa & Fruit & Ficus sarmentosa & Fruit \\
\hline Ficus sarmentosa & Fruit & Hedyotis lineata & Bark, petiole \\
\hline Hedyotis lineata & Bark, petiole & Justicia adhatoda & Flower \\
\hline Justicia adhatoda & Flower & Lagerstroemia parviflora & Young leaf \\
\hline Lannea coromandelica & Young leaf, flower & Lannea coromandelica & Young leaf, flower \\
\hline Madhuca longifolia & Mature leaf & Madhuca longifolia & Mature leaf \\
\hline Maesa montana & Mature leaf, young shoot & Maesa montana & Mature leaf, young shoot \\
\hline Magnifera indica & Fruit & Magnifera indica & Fruit \\
\hline Mallotus philippensis & Mature leaf & Mallotus philippensis & Mature leaf \\
\hline Melastoma malabathricum & Fruit & Melastoma malabathricum & Fruit \\
\hline Melia azedarach & Mature leaf & Melia azedarach & Mature leaf \\
\hline Michelia champaca & Young leaf & Michelia champaca & Young leaf \\
\hline Milletia extensa & Mature leaf & Milletia extensa & Mature leaf \\
\hline Milletia fruticose & Mature leaf & Milletia fruticose & Mature leaf \\
\hline Morus macroura & Fruit, mature leaf & Morus macroura & Fruit, mature leaf \\
\hline Musa superfa & Fruit & Myrica esculenta & Fruit, mature leaf \\
\hline Myrica esculenta & Fruit, mature leaf & Osyris wightiana & Mature leaf \\
\hline Odina wodier & Mature leaf & Phyllanthus emblica & Fruit, mature leaf \\
\hline Osyris wightiana & Mature leaf & Prunus cerasoides & Fruit, mature leaf \\
\hline Phyllanthus emblica & Fruit, mature leaf & Pyrus pashia & Fruit \\
\hline Premna scandens & Mature leaf, young leaf & Rubus ellipticus & Fruit \\
\hline Prunus cerasoides & Fruit, mature leaf & Rubus rugosus & Fruit \\
\hline Pyrus pashia & Fruit & Shorea robusta & Young leaf, flower \\
\hline Rubus ellipticus & Fruit & Spondias pinnata & Fruit \\
\hline Rubus rugosus & Fruit & Syzygium cumini & Fruit, young leaf \\
\hline Shorea robusta & Young leaf, flower & Syzygium jambos & Fruit \\
\hline Sphaerosacme decandra & Mature leaf & Terminalia alata & Young leaf, seed, bark \\
\hline Spondias pinnata & Fruit & Terminalia bellirica & Fruit \\
\hline Syzygium cumini & Fruit, young leaf & Terminalia chebula & Fruit, mature leaf \\
\hline Syzygium jambos & Fruit & Thysanolaena maxima & Young shoot \\
\hline Terminalia alata & Young leaf, seed, bark & Toona ciliata & Mature leaf \\
\hline Terminalia bellirica & Fruit & Trichilia connaroides & Fruit \\
\hline Terminalia chebula & Fruit, mature leaf & Woodfordia fruiticosa & Mature leaf, young leaf, flower \\
\hline Thysanolaena maxima & Young shoot & Zizyphus mauritiana & Fruit \\
\hline Toona ciliata & Mature leaf & Zizyphus rugose & Fruit \\
\hline Trichilia connaroides & Fruit & - & - \\
\hline Woodfordia fruiticosa & Mature leaf, young leaf, flower & - & - \\
\hline
\end{tabular}

